\title{
Os sessenta anos do Instituto Brasileiro de Relações Internacionais
}

\author{
Sixty years of the Brazilian Institute of International Relations
}

http://dx.doi.org/10.1590/0034-7329201400301

ANTÔNIO CARLOS LESSA*

PAULO ROBERTO DE ALMEIDA**

Rev. Bras. Polít. Int. 57 (2): 5-8 [2014]

Talvez - e aqui vai um pouco de imaginação - o punhado de intelectuais, de acadêmicos, de burocratas de alto coturno (entre eles vários diplomatas e magistrados), de vários outros mandarins públicos e privados da República de 1946, que se reuniu no velho Palácio do Itamaraty, no Rio de Janeiro, no final do mês de janeiro de 1954, para fundar o Instituto Brasileiro de Relações Internacionais (IBRI), talvez esse pequeno grupo de desbravadores de um terreno ainda inexplorado no Brasil estivesse pensando no modelo do Council on Foreign Relations, dos Estados Unidos, como uma fonte de inspiração para a fundação, o estabelecimento oficial e o funcionamento prático da nova instituição que então surgia de forma inédita no país, no governo constitucional de Getúlio Vargas.

Pode ser. É legítimo supor que aquelas personalidades bem informadas, todas elas cosmopolitas, abertas aos ares do mundo, conhecessem o trabalho do Conselho de Nova York, provavelmente pela existência de seu principal instrumento de análise, de reflexões e de prescrições sobre a política internacional e para a diplomacia americana, a Foreign Affairs, sobretudo porque a revista havia completado seu primeiro quarto de século pouco tempo antes, e seu editor havia feito um Reader comemorativo na ocasião. Ela já era intensamente lida nesses meios conectados às realidades da política mundial na era da Guerra Fria, e o volume especial, reunindo os textos mais significativos dos 25 anos anteriores, tinha sido publicado justamente quando certo Mr. X, o diplomata George Kennan, ainda baseado em Moscou, havia publicado um artigo intrigante sobre as fontes do poder soviético, que constituiria não só a base conceitual, mas também a legitimação política para a doutrina do containment, que seria rigorosa e religiosamente

\footnotetext{
* Instituto de Relações Internacionais, Universidade de Brasília, Brasília, Brasil (aclessa@gmail.com).

** Ministério das Relações Exteriores, Brasília, Brasil (paulomre@gmail.com).
} 
aplicada pelos EUA no meio século seguinte, até praticamente a derrocada da União Soviética.

Talvez. Não sabemos, de fato, qual era o pensamento dominante entre aqueles visionários, que queriam colocar o Brasil no mapa da análise, da reflexão, e da ação em temas de política internacional, conceito que acabou sendo impresso no título da revista que surgiria pouco mais de quatro anos depois, período extremamente movimentado sob qualquer critério que se examine no contexto de nossa história republicana: suicídio do presidente incumbente - do qual, aliás, vários dos fundadores do IBRI eram assessores diretos -, seguido da sucessão tumultuada de três outros presidentes, de golpes e contragolpes, com a participação de militares, de uma campanha eleitoral e da posse de um presidente contestada como inconstitucional pelo principal líder da oposição - e que depois seria um dos mentores do golpe de 1964 -, de todo um clima de efervescência geral no país, de otimismo pela promessa dos "cinquenta anos em cinco", mas também um período permeado por mais tentativas de sublevações militares, marcado por um rebrote preocupante da inflação, bastante empurrada pela construção de Brasília e pelas primeiras diatribes contra o FMI, então demonizado politicamente como um "obstrutor" do desenvolvimento brasileiro. Foi nesse ambiente febril que surgiu a Revista Brasileira de Política Internacional, que em breve também comemorará os seus 60 anos.

O Reader da Foreign Affairs, volume especial publicado pelo Council em 1947, já estava integrado à Biblioteca do Itamaraty, e seu artigo inaugural tinha sido assinado pelo então decano da diplomacia americana, Elihu Root, que tinha estado no Rio de Janeiro em 1906, para uma das conferências das repúblicas americanas, acolhida por Rio Branco, sob recomendação de Joaquim Nabuco, mas cujas posições pró-império já eram contestadas por um competidor de ambos, o historiador Oliveira Lima. Pode ser, ainda assim, que os "pais fundadores" do IBRI se inspirassem no modelo do Council, e da Foreign Affairs, e tomassem inspiração nas figuras de Rio Branco e de Elihu Root para impulsionar um projeto que não só sobreviveu às intempéries políticas que soem se abater sobre um país em estado de recriação permanente como é o Brasil. Mas é um fato que esse empreendimento desafiador foi mantido por mais de duas geraçôes, em duas capitais da República, por cosmopolitas dedicados, que têm a intenção de fazê-lo chegar ao seu primeiro centenário, da mesma forma como o fará, dentro de pouco mais de sete anos, o Council e a própria Foreign Affairs.

É certo que o IBRI não se converteu, nem poderia, num êmulo do Council, que pôde dispor, desde sua origem, dos enormes recursos da aristocracia endinheirada da costa leste dos Estados Unidos, do prestígio associado ao establishment acadêmico da região atlântica e do próprio cadinho cultural e cosmopolita de Nova York, a mais internacionalizada das metrópoles daquele país, até mesmo mais do que Washington, uma vez que a ONU, os bancos de Wall Street, os milhões de turistas estrangeiros e de imigrantes, antigos e recentes, fazem daquela cidade uma 
aglomeração multinacional por excelência. O IBRI, na verdade, sequer dispunha de locais apropriados, abrigado de favor aqui e ali, até se instalar, nos últimos anos, na Fundação Getúlio Vargas do Rio de Janeiro, de onde foram trasladados alguns poucos arquivos quando de sua transferência, na verdade a sua recriação em Brasília, em 1993. Ele nunca dispôs de uma conta em banco que fosse minimamente capaz, como fazia o Council, de manter staff próprio, pesquisadores contratados, bolsistas convidados, e empreender projetos de certa magnitude. Os livros de sua pequena biblioteca - cedida para a FGV quando da despedida do Rio - foram obtidos em doações de seus associados, em intercâmbio com instituições estrangeiras e nacionais, ou adquiridos com os recursos de seus próprios membros.

A figura de Cleantho de Paiva Leite, depois do presidente inaugural do IBRI, Oswaldo Trigueiro, do diplomata Henrique Valle e do historiador José Honório Rodrigues, na RBPI, merece aqui uma menção especial, e uma reverência obrigatória, pois foi ele o animador principal, o editor "eterno" e o financiador pessoal do Instituto e de sua revista, que permanece como a realização principal, quase única, do IBRI. Escrevendo, no volume 35, n. 139-140 (julho-dezembro de 1992), ainda sob o impacto da morte de Cleantho, o Embaixador Sérgio Bath, um dos recriadores do IBRI e da $R B P I$ em Brasília, disse que em todas as atividades em que ele se engajou,

Cleantho marcou sua presença pelo otimismo, a disposição para o trabalho, o espirito criativo; a seriedade de propósitos temperada por perene bom humor. Em toda parte, em muitos países fez numerosos amigos; no Itamaraty, no DASP, no BID, no BNDE, era uma figura carinhosamente respeitada. Conheceu bem a sua geração, e quando falava sobre o passado reconstruía com riqueza de pormenores e acentos pessoais a trama de muitas vidas, comentando-as com sorriso ameno, a percepção aguda de humor e empatia. Realista, compreendia e aceitava os defeitos alheios, que coloria com benevolência; mantinha-se conciliado com o mundo, acentuando sempre o melhor, em todos e em tudo. Cultivava intensa dedicação aos amigos, que fazia questão de servir. Nada o agradava mais do que receber a encomenda de um livro recém-publicado, dar um conselho, uma indicação útil. A amizade era para ele uma arte, que praticava com prazer.

O IBRI, em sua fase de Brasília, empreendeu diversos convênios, realizou muitos seminários - vários deles internacionais, em cooperação com universidades e instituiçôes congêneres do exterior - e editou muitos livros, que hoje integram qualquer lista de referência na literatura especializada na área que é a sua, desde a origem. A RBPI constitui, sem qualquer sombra de dúvida, o mais belo fruto deste instituto, que nunca foi um impávido colosso, como seu êmulo de Nova York, mas que não deixa de ser a moldura institucional indispensável para que o projeto inaugurado em 1954 possa evoluir para etapas ainda mais brilhantes de um itinerário modestamente exemplar. 
A RBPI, decana das revistas especializadas em Relações Internacionais no Brasil, e uma das mais tradicionais da América Latina, realmente desponta como o projeto mais constante do IBRI. A transferência para Brasília, juntamente com o IBRI em 1993, foi o mais importante passo da já longa trajetória da Revista, porque lhe permitiu a confirmação da sua identidade científica, a partir de então mantida e velada consistentemente por professores de Relaçôes Internacionais da Universidade de Brasília.

O IBRI agora se prepara para celebrar também, em 2017, o sexagésimo aniversário da publicação do primeiro volume da Revista. Ao longo da sua história brasiliense, o IBRI e os professores e diplomatas que animam a instituição, não pouparam energias e recursos para manter a Revista como o seu grande empreendimento intelectual, que a essas alturas, já é um patrimônio de toda a comunidade brasileira de Relações Internacionais.

\section{Referência bibliográfica}

BATH, Sérgio. Cleantho de Paiva Leite (1921-1992). Revista Brasileira de Política Internacional, Vol. 35, No. 139-140, 1992. 